\title{
Perceptions of Selected Stakeholders on the Use of Tablets for University Teaching
}

\author{
Simon Christopher Fernandez ${ }^{1}$, Kuttickattu John Mammen ${ }^{2}$ \\ ${ }^{1}$ Walter Sisulu University, Department of Applied Informatics \& Mathematical Sciences, \\ East London, South Africa \\ ${ }^{2}$ University of Fort Hare, School of General \& Continuing Education, East London, South Africa
}

\begin{abstract}
The purpose of this study was to examine the perceptions of lecturers and managers as selected stakeholders on the use of tablet computers in teaching at a South African university. The study adopted a mixed method approach. A sample of 14 lecturers from a population of 25 voluntarily participated in the survey. Additionally, five lecturers and nine managers were interviewed. Findings showed that both stakeholders had viewed tablets as an effective teaching tool. Furthermore, teaching skills of the lecturers were enhanced due to the use of tablets and it made completion of their work faster.
\end{abstract}

Keywords - Tablet Computers, Teaching, Mobile Technology, Stakeholders' Perceptions, University.

\section{Introduction}

The methodology of teaching using technologies has revolutionized education all over the globe, especially in higher education sectors [1]. Technologies are rapidly growing up and it reflects in all areas of works, so in education as well [2].

Higher education institutions provide internet access to lecturers and students with an intention to make use of all kinds of learning and teaching by using

DOI: $10.18421 /$ TEM94-64

https://doi.org/10.18421/TEM94-64

Corresponding author: Simon Christopher Fernandez, Walter Sisulu University, South Africa.

Email: wsusimon@gmail.com

Received: 08 June 2020.

Revised: 07 November 2020.

Accepted: 14 November 2020.

Published: 27 November 2020.

(cc) BY-NC-ND (C) 2020 Simon Christopher Fernandez \& Kuttickattu John Mammen; published by UIKTEN. This work is licensed under the Creative Commons AttributionNonCommercial-NoDerivs 4.0 License.

The article is published with Open Access at www.temjournal.com different tools such as desktop computers, laptops, tablets, projectors etc [3].

Among all the mobile technologies, tablet is the latest technology that has created a boom in all sectors especially in education [4]. Furthermore, tablets can be used anywhere at any time. Therefore, teachers can use this device to foster students learning [5]. Tablets are revolutionizing the learning and teaching environment from traditional method to blended method [6]. Educators should be updated with the knowledge of latest technologies in the current market such as tablets and smart phones for appraisal and professional development which also helps to communicate between student-teacherparent effectively and become familiar with tablet technology [7]. Agir [7] argues that they should be pedagogically trained on how to use tablets effectively in the learning and teaching environment with the assistance of various new applications ("apps") to improve the deliverance of content to students in classroom. Plenty of educational apps are available in the tablets for effective learning and teaching [8]. Instructional practices and obtaining degrees will all be done using new educational apps installed in mobile learning devices by the year 2024 [9].

A combination of face to face and tablet based instruction have made substantial developments in students' learning outcomes [10]. The use of tablets for instructional practice has drawn positive responses from the lecturers to a certain extent [11]. On the other side, some other studies showed that lecturers had a negative perspective towards the use of tablet technology [12] due to the lack of proper training and professional development [13]. Moreover, Flanagan's [14] research shows that lecturers were not impressed with students' use of tablet in classroom.

As indicated earlier, many higher education institutions ubiquitously have started integrating tablets in classroom. However, lecturers are in the dark as they attempt to integrate these devices in effective ways [15]. There is also a lack of study on how to integrate tablet technology in the classroom 
for effective results [16]. Although tablets are the latest technologies used in universities for teaching, there are some serious gaps such as how lecturers are using tablets in classroom, the perceptions of managers about the use of tablets by the lecturers for teaching still pending that need to be addressed in this research. Many South African institutions are either integrating or planning to integrate tablets, yet none seems certain of the outcomes or the process to undertake to ensure that the devices serve their intended purposes. To date there is little published research to confirm that tablets are valuable to classroom instruction, especially in the South African context [15]. Poore [17] states that empirical studies on the tablet teaching practice are highly limited which further makes the current study an inevitable research. Therefore, gathering and analyzing the perceptions of lecturers and managers on the use of tablets for teaching is a worthy problem for investigation.

\section{Literature Review}

A research conducted to examine the perspective of faculties on deploying tablets at the Higher Colleges of Technology (HCT) and Abu Dhabi Women's College (ADWC) campus in Abu Dhabi shows that the device has highly influenced the faculties in terms of professional development. Case study interviews and survey were used for the study. While a sample of 4 instructors out of 30 participated in the case study, 224 out of 325 faculty members participated in the survey. The case study was analyzed using the framework of SWOT (strengths, weaknesses, opportunities and threats). The adoption of tablets helped to create an active student- centered education and encouraged other technical colleges to integrate the new digital content [18].

Contrary to the above study, Percival and Claydon [13] argue that even though a tablet is a weight less tool that is portable and easier to handle, faculty members expressed strong concerns on how to use the tablet effectively in their teaching. In order to investigate the use of tablets in the higher education sector, the authors interviewed lecturers who had used tablets in classrooms. The majority of them struggled to type on the keyboard as it was tiny. The tablets could not be connected to the projector, which was another reason for their concern. Lack of proper training and professional development, caused many academics to struggle to get familiar with the tablet and they preferred to stick to the traditional approach which was teacher-centered approach.

Shen [19] conducted a research to evaluate the experiences of teacher educators regarding tablet use in teacher education from 2013-2015. The study took place in the School of Education at a Midwestern private university in the United States of America. Five, four and three faculties participated in the fall semesters of 2013, 2014 and 2015 respectively. However, three faculties in the fall semester of 2015 were the same faculties who had participated in the fall semesters of 2013 and 2014. Data was collected through semi structured interview. In 2013, the researcher conducted face-to-face interview and the responses were recorded and transcribed. On the other hand, responses in 2014 and 2015 were collected through mail. During this three year cycle, faculties who used tablets on a regular basis in lecturing had incorporated into the curriculum. However, majority of the faculties had not used the digital technology very often and used it maximum of twice in a semester.

A survey based on a quantitative study was conducted to investigate the attitudes of administrators and educators regarding the use of tablets in classroom in a south western state. Administrators included the principal and vice principals of various institutions. A total of 51 administrators participated in the study. The researchers developed two survey instruments such as pre survey and post survey and administered to collect the data. The results showed that administrators were impressed with the training that the lecturers received to enhance their talents and knowledge on tablet use for professional duties. Administrators were also glad with the present and future use of tablets by teachers and students in the classroom [20].

A case study conducted by Flanagan [14] examined the use of tablets to provide information in connection with the process of incorporating similar technologies and thereby investigating the effects of student learning from the perspective of administrators. Two administrators comprising of the principal and vice principal participated in the interview process. Findings of this qualitative study elicited a positive response regarding the implementation of tablets in instructional strategies.

The aim of this study was to examine the perceptions of lecturers and managers as selected stakeholders on the use of tablet computers in teaching at a South African university. This study was guided by the following research question: What are the perceptions of lecturers and managers on the use of tablets for teaching in university classrooms?

\section{Methods}

\section{Research Approach and Design}

The study adopted mixed method research approach because different instruments used to collect the data aided to provide important and valid 
information to this study. The research design was a case study using survey and interview where quantitative data were collected first followed by qualitative data.

\section{Study Site and Context}

The study was conducted at a university situated in the Eastern Cape province of South Africa because this was the only university from this region where tablets were used for teaching. Moreover, it was convenient for the main researcher to collect the data as he works as a lecturer in the same university.

\section{Population and Sample}

While quantitative data were collected only from lecturers, qualitative data were collected from both lecturers and managers. A total sample of 14 lecturers ( 9 male; 5 female) that comprised of Information and Communication Technology (ICT) department and Electrical Engineering (EE) department from a population of 25 voluntarily participated in the survey. Moreover, five lecturers from the ICT and EE cohorts and nine managers were also interviewed. The managers included the Deans, Heads of various departments, e-learning specialists, e-learning administrators, extended program coordinators and Institutional Head of Extended program coordinators. The tablets were supplied to the lecturers in ICT and EE cohorts in 2014. All lecturers who participated in this study were using tablets for the purpose of teaching.

\section{Data Collection Instruments}

The researchers developed a five-point Likert-scale questionnaire and it consisted of two sections in which the first section was used to collect the demographic data and the second section was used to collect the core data. A total of nine items were included in the second section of questionnaire. The scale of questionnaire ranged from level 1 to level 5 in which level $1=$ "STRONGLY DISAGREE" and level 5 = "STRONGLY AGREE". The researchers used many sources to create the questionnaire. Some of the statements that were used by other researchers [7], [21], [22] in their researches had been reformed and used in this study. A pilot study was conducted with five lecturers to measure the validity of Likertscale questionnaire. The Cronbach's alpha reliability was calculated and the result was 0.754 . A total of four key questions were asked to collect data from lecturers and five key questions were asked to collect data from managers. Additionally, the main researcher had done a trial run for the interview with three lecturers and three managers by inquiring, listening and recording for the correctness, reliability and smooth running of the interviews. All who participated in the pilot study were not included in the main study.

\section{Ethical Compliances and Data Collection Procedures}

The researchers attended to ethical issues such as Human ethics approval from the university and informed consent from participants. The questionnaire were emailed to all the lecturers and the responded questionnaires were received back from them after reminding them through WhatsApp, Short Message Service and voice call. Response rate was $64 \%$. The main researcher organized his office itself as the venue to interview all lecturers, Deans and HODs. However, other managers preferred their own office due to their convenience. The main researcher used high quality smart phone and professional audio recording device to record the interviews and ensure that no information was lost. All ethical compliances were met during the time of interview to ensure that respondents were not harmed physically and mentally. Data was collected from all participants at the end of 2017.

\section{Data Analysis}

The researchers manually entered the quantitative data into Statistical Package for Social Sciences (SPSS version 24). While descriptive statistics was used to analyze quantitative data, thematic analysis was used to analyze qualitative data. The researchers transcribed and analyzed the data collected through interview. Major themes and sub-themes were generated to understand the in-depth knowledge on the use of tablets for teaching in classroom. Furthermore, triangulation was done to confirm the findings. 


\section{Results}

Table 1. Perceptions of lecturers on the use of tablets for teaching

\begin{tabular}{|c|c|c|c|c|c|c|}
\hline \# & ITEMS & DIS & NO & AGR & $\mathbf{N}$ & NA \\
\hline B1 & I use tablets for most of my lecture classes. & $\begin{array}{c}2 \\
(18.1 \%)\end{array}$ & $\begin{array}{c}0 \\
(0 \%)\end{array}$ & $\begin{array}{c}9 \\
(81.2 \%)\end{array}$ & $\begin{array}{c}11 \\
(78.5 \%)\end{array}$ & $\begin{array}{c}3 \\
(21.4 \%)\end{array}$ \\
\hline B2 & Tablet enhances the tasks during lectures. & $\begin{array}{c}1 \\
(8.3 \%)\end{array}$ & $\begin{array}{c}3 \\
(25 \%) \\
\end{array}$ & $\begin{array}{c}8 \\
(66.6 \%) \\
\end{array}$ & $\begin{array}{c}12 \\
(85.7 \%)\end{array}$ & $\begin{array}{c}2 \\
(14.2 \%)\end{array}$ \\
\hline B3 & $\begin{array}{l}\text { With students' use of tablets, I see } \\
\text { distraction in class while I am lecturing. }\end{array}$ & $\begin{array}{c}3 \\
(21.4 \%) \\
\end{array}$ & $\begin{array}{c}3 \\
(21.4 \%)\end{array}$ & $\begin{array}{c}8 \\
(57.1 \%) \\
\end{array}$ & $\begin{array}{c}14 \\
(100 \%)\end{array}$ & $\begin{array}{c}0 \\
(0 \%)\end{array}$ \\
\hline B4 & $\begin{array}{l}\text { The use of tablet helps me to finish the } \\
\text { topics fast. }\end{array}$ & $\begin{array}{c}3 \\
(23 \%)\end{array}$ & $\begin{array}{c}3 \\
(23 \%)\end{array}$ & $\begin{array}{c}7 \\
(53.7 \%)\end{array}$ & $\begin{array}{c}13 \\
(92.8 \%)\end{array}$ & $\begin{array}{c}1 \\
(7.1 \%)\end{array}$ \\
\hline B5 & $\begin{array}{l}\text { The use of tablet helps me to develop my } \\
\text { teaching skills. }\end{array}$ & $\begin{array}{c}1 \\
(7.1 \%) \\
\end{array}$ & $\begin{array}{c}5 \\
(35.7 \%) \\
\end{array}$ & $\begin{array}{c}8 \\
(57.1 \%) \\
\end{array}$ & $\begin{array}{c}14 \\
(100 \%) \\
\end{array}$ & $\begin{array}{c}0 \\
(0 \%) \\
\end{array}$ \\
\hline B6 & $\begin{array}{l}\text { The use of tablet helps me to finish the } \\
\text { syllabus as per the schedule. }\end{array}$ & $\begin{array}{c}1 \\
(7.6 \%) \\
\end{array}$ & $\begin{array}{c}4 \\
(30.7 \%)\end{array}$ & $\begin{array}{c}8 \\
(61.4 \%) \\
\end{array}$ & $\begin{array}{c}13 \\
(92.8 \%)\end{array}$ & $\begin{array}{c}1 \\
(7.1 \%)\end{array}$ \\
\hline B7 & $\begin{array}{l}\text { Using personal computer (PC) makes better } \\
\text { impact in students than using tablets. }\end{array}$ & $\begin{array}{c}2 \\
(14.2 \%)\end{array}$ & $\begin{array}{c}7 \\
(50 \%) \\
\end{array}$ & $\begin{array}{c}5 \\
(35.6 \%)\end{array}$ & $\begin{array}{c}14 \\
(100 \%)\end{array}$ & $\begin{array}{c}0 \\
(0 \%)\end{array}$ \\
\hline B8 & $\begin{array}{l}\text { Tablet usage has made my work easier in } \\
\text { lecturing. }\end{array}$ & $\begin{array}{c}4 \\
(28.5 \%)\end{array}$ & $\begin{array}{c}3 \\
(21.4 \%)\end{array}$ & $\begin{array}{c}7 \\
(50 \%)\end{array}$ & $\begin{array}{c}14 \\
(100 \%)\end{array}$ & $\begin{array}{c}0 \\
(0 \%)\end{array}$ \\
\hline B9 & $\begin{array}{l}\text { Overall, I prefer personal computers than } \\
\text { using tablets. }\end{array}$ & $\begin{array}{c}3 \\
(21.3 \%)\end{array}$ & $\begin{array}{c}6 \\
(42.8 \%)\end{array}$ & $\begin{array}{c}5 \\
(35.6 \%)\end{array}$ & $\begin{array}{c}14 \\
(100 \%)\end{array}$ & $\begin{array}{c}0 \\
(0 \%)\end{array}$ \\
\hline
\end{tabular}

where \# = item number DIS = Disagree, $N O=$ No Opinion, $A G R=$ Agree, $N=$ Total answered and $N A=$ No Answer .

\section{Quantitative Findings}

When Strongly Disagree and Disagree columns in the questionnaire were collapsed into Disagree (DIS), the percentage of lecturers' responses was $18.1 \%$ (Item B1), 8.3\% (Item B2), 21.4\% (Item B3), 23\% (Item B4), 7.1\% (Item B5), 7.6\% (Item B6), 14.2\% (Item B7), 28.5\% (Item B8) and 21.3\% (Item B9).

It can be seen from Table 1 that $81.2 \%$ of the lecturers agreed on item B1 and above $61 \%$ of lecturers agreed on item B2 and item B6. About $57.1 \%$ of lecturers agreed on item B3 and item B5. While $53.7 \%$ of lecturers agreed on item B4, only $50 \%$ agreed on item B8. Furthermore, $35.6 \%$ of the lecturers agreed on item B7 and item B9. Three lecturers each were uncertain on item B2, item B3, item B4 and item B8. Five lecturers on item B5, four lecturers on item B6, seven lecturers on item B7 and six lecturers on item B9 were also uncertain. While $21.4 \%$ of lecturers did not answer item B1 and 14.2\% of lecturers did not answer item B2, 7.1\% of lecturers did not answer item B4 and item B6.

\section{Qualitative Findings}

The researchers had used pseudonyms such as LectInter and ManInter along with the numbers to refer all the lecturers and managers respectively. The major theme that was generated after the data collection was "tablet use for teaching". The three sub themes that had emerged from the major theme after collecting interview responses from lecturers are "tablet training", "teaching apps" and "before integrating tablets".
On the aspect of first sub theme: "tablet training", the researchers received a mixture of responses. Some respondents mentioned that they had received training. Other respondents indicated that they had not received any training for tablet use. One respondent mentioned that he received training. However, it was not the training that Centre for Learning and Teaching Development (CLTD) were supposed to provide.

On the aspect of second sub theme: "teaching apps", most of the respondents alluded to the fact that they weren ot using pedagogical apps for lecturing. Only one respondent indicated that she used different apps in the classroom. LectInter 2 commented "The newly tablets are coming with the apps but I haven't explored them yet but I think they're useful". LectInter 1 and LectInter 4 stressed that they did not use teaching apps which were installed in tablets. While LectInter 3 used the pedagogical apps such as Excel, Word, PowerPoint and Microsoft Publisher, LectInter 5 used tablets only for Blackboard or Wiseup app for the purpose of effective teaching.

On the aspect of third sub theme: "before integrating tablets", respondents indicated that it was challenging before integrating tablets and now it is much easier to teach in classroom. LectInter 4 commented "It was challenging in the olden days. We have to print the notes for them so it was a challenging in the preparation of going to the class". LectInter 3 stated "It was difficult at that time because we need to draw the diagram on the board".

The four sub themes that had emerged from the major theme after collecting interview responses from managers are "after integrating tablets", "tablet 
training", "enhancement of skills" and "syllabus/curriculum change for tablets".

On the aspect of first sub theme: "after integrating tablets", all the respondents responded positively due to the tremendous change that they had witnessed in lecturers' instructional methodology.

On the aspect of second sub theme: "tablet training", all the respondents had the same response that lecturers had received training in order to use the tablet effectively in classroom for the purpose of teaching. ManInter 9 added that from the following year onwards more intensive trainings were going to be conducted for lecturers. ManInter 4 argued "The department itself has not done any training but there was a training that was offered by CLTD department in order to use the tablets effectively in the classroom for teaching purpose".

On the aspect of third sub theme: "enhancement of skills", use of tablets in classroom made a positive impact on lecturer's skill and instructional methodology. In ManInter 6's point of view, these tablets have to be provided to the other lecturers also who are lecturing the main stream courses in the university as it had enhanced the teaching capability of extended stream lecturers.

On the aspect of fourth sub theme: "syllabus/curriculum change for tablets", majority of the respondents averred that there was no need to change the syllabus/curriculum. ManInter 9 articulated that rather than changing the syllabus, syllabus plan has to be changed and it had to be done by lecturers in each department. This would help the CLTD to understand what gadgets were required for each lecturer to lecture each topic effectively in their curriculum.

The common sub theme that was emerged from the major theme after collecting responses from both stakeholders was "tablet training".

\section{Discussion}

\section{Survey Responses}

Most of the lecturers in the current study indicated that they used tablets for most of their lecture classes (item B1) which is inconsistent to the results found by Lindsey [23]. Findings by Lindsey [23] show that only $37 \%$ of the academics used tablets for teaching.

The results obtained from the current survey showed that tablet enhanced lecturers' tasks during lectures (item B2) which is consistent with the finding by Agir [7] who states that the use of tablets support the task of academics.

The current study showed that majority of the lecturers stressed that there was much distraction in class during the lecture hours (item B3). Findings by Gong and Wallace [24] advocate that more than 50\% of the respondents' in their study stated that they used tablets more for entertainments in classroom than learning which eventually resulted in the distractions in class. Rossing, et al. [21] argue that using of tablets without clear intension will lead to distraction in classroom. Therefore, findings of the current study are similar with the findings by Rossing, et al. [21] and Gong and Wallace [24].

The current research showed that lecturers could quickly finish their topics using tablets (item B4) which are stable with the findings by Agir [7] who concurs that topics can be easily completed by using iPad tablets.

Lecturers agreed that tablets helped them to develop their teaching skills (item B5) which substantiates with the findings by Rossing, et al. [21] and Diemer et al. [22] who indicate that tablet helps to develop the skills that can applied to professional life.

Majority of lecturers agreed that they could finish the syllabus as per the schedule (item B6). Agir [7, p. 187] states that "Most of the teachers (94\%) think that the teaching curriculum can be completed by using iPads". Therefore, findings of the present study coincide with the findings by Agir [7].

This study found that lecturers indicated a neutral stance on the statement "Using personal computers (PC) makes better impact on students than using tablets" (item B7). Only a small group of lecturers supported to this statement. Mang and Wardley [25] articulate that tablets should be considered as an extra tool along with personal computer which harmonizes with the findings of the current study.

Use of tablets made lecturers work easy while lecturing (item B8) which is similar to the findings by Agir [7, p. 186] who concurs that "iPad usage facilitates the task of teachers".

It emerged from the study that a small group of lecturers preferred personal computers than using tablets (item B9). Most of them were opted for a neutral stand which did not substantiate with the findings by Hill, Nuss, Middendorf, Cervero, and Gaines [26] and Rossing, et al. [21] who state that iPad tablets were more useful compared to a desktop computer.

\section{Interview Responses}

The study found that the lecturers were not using apps for the purpose of teaching. Chou, Block, and Jesness [27] argue that lack of teacher selected apps was one of the challenges for teaching. The finding of this study is therefore consistent with the views of Chou et al. [27].

Most of the lecturers mentioned that it was challenging during the earlier days and now it is easy to lecture after the adoption of tablets in the 
classroom which is in line with the investigations by Agir [7] who indicates that use of iPad tablets simplified the task of academics. Moreover, quantitative data (item B8) corroborated this finding.

From the managers' point of view, the lecturers were using tablets for various teaching purposes and their tablet use depended on the topic that they were lecturing in class. Chou et al. [27] indicate that academics use apps with updated information in Geography to engage with students. The results obtained from managers are stable with the findings by Chou et al. [27].

Majority of the managers averred that there was no need to change the syllabus/curriculum which concurs with the findings by Agir [7, p.186] who states that currently "the curriculum can be finished on time by using iPad".

Most of the managers assert that lecturers had received training to use the tablets effectively for the purpose of teaching. "There was a faculty's training workshop conducted in order to kick start for the iPad's initiative" [19, p.18]. Therefore, findings of this study uphold with the findings by Shen [19]. However, it was mixed responses that were received from lecturers.

\section{Conclusion}

The evidence from this study underscored that both lecturers and managers viewed tablets as an effective teaching tool in the university classrooms. However, in order to realize this, the necessary apps have to be installed. Teaching skills of the lecturers were enhanced due to the use of tablets and it made completion of their work faster. They also believed that tablet was a tool for teaching the existing curriculum which was not needed to be changed. It is important to provide training or workshops to the lecturers for the effective use of tablets for teaching. Half of the lecturers claimed that the training provided by CLTD, which they attended was effective. However, the remaining lecturers indicated that they did not receive training and they were exploring tablets by themselves. Even though mobile devices such as e-reader and smart phones are used all over the globe, an assumption cannot be made that all lecturers know how to use tablets without proper guidance. In the researcher's view, CLTD must track out the lecturers who did not receive training and offer them training for the effective use of tablets in teaching.

\section{Implications for Further Research}

It is expected that the findings of this research will stimulate further research on other areas such as strengths and weaknesses of lecturers' use of tablets in universities and teachers' use of tablets in schools.

\section{Recommendations}

This research has generated the following recommendations to the management of higher education institutions and schools on how well tablets could be used to support teaching.

a) Proper training has to be offered to all lecturers on how to use the tablet effectively for teaching.

b) Proper training has to be offered to all lecturers on the necessary apps and how to use them.

c) All necessary apps have to be installed prior to the distribution of tablets to the lecturers.

\section{Limitations}

One of the limitations was that the lecturers in this study were only from ICT and EE cohorts. It would be beneficial to conduct a similar case study with the lecturers from other departments in the same university to assess the difference in the findings. The sample consisted of only 14 lecturers and this could be another limitation.

\section{References}

[1]. Castillo-Manzano, J. I., Castro-Nuño, M., LópezValpuesta, L., Sanz-Díaz, M. T., \& Yñiguez, R. (2017). To take or not to take the laptop or tablet to classes, that is the question. Computers in Human Behavior, 68, 326-333.

[2]. Zydney, J. M., \& Warner, Z. (2016). Mobile apps for science learning: Review of research. Computers \& Education, 94, 1-17.

[3]. Suthers, D. D. (2006). Technology affordances for intersubjective meaning making: A research agenda for CSCL. International Journal of ComputerSupported Collaborative Learning, 1(3), 315-337.

[4]. Cochrane, T., Narayan, V., \& Oldfield, J. (2013). iPadagogy: Appropriating the iPad within pedagogical contexts. International Journal of Mobile Learning and Organisation, 7(1), 48-65. doi: 10.1504/IJMLO.2013.051573.

[5]. Melhuish, K., \& Falloon, G. (2010). Looking to the future: M-learning with the iPad. Computers in New Zealand Schools: Learning, Leading, Technology. 22(3), 1-16.

[6]. Kiger, D., Herro, D., \& Prunty, D. (2012). Examining the influence of a mobile learning intervention on third grade math achievement. Journal of Research on Technology in Education, 45(1), 61-82. doi: $10.1080 / 15391523.2012 .10782597$. 
[7]. Ağır, A. (2015). iPad at School: A holistic evaluation of the opinions of students, teachers and parents concerning ipad usage. International Journal of Education, 7(3), 175-193. doi:10.5296/ije.v7i3.7924.

[8]. Cohen, S. (2012). Apps meet the common core state standards in writing. Teacher Librarian, 40(2), 32.

[9]. Alexander, B. (2014). Higher Education in 2024: Glimpsing the future. Educause Review Online. Retrieved from:

http://er.educause.edu/articles/2014/9/highereducation-in-2024-glimpsing-the-future [accessed: 10 May 2020].

[10]. Walczak, S., \& Taylor, N. G. (2018). Geography learning in primary school: comparing face-to-face versus tablet-based instruction methods. Computers \& Education, 117, 188-198. doi: 10.1016/j.compedu. 2017.11.001.

[11]. Vu, P., McIntyre, J., \& Cepero, J. (2014). Teachers' use of the iPad in classrooms and their attitudes toward using it. Journal of Global Literacies, Technologies, and Emerging Pedagogies, 2(2), 58-74.

[12]. Beckerle, A. L. (2013). A mixed method study measuring the perceptions of administrators, classroom teachers and professional staff on the use of iPads in a Midwest school district (Doctoral dissertation, Lindenwood University).

[13]. Percival, J. \& Claydon, T. (2015). A Study of student and instructor perceptions of tablet PCs in higher education contexts. Higher Education in Transformation Conference. Dublin, Ireland: ARROW@DIT.

[14]. Flanagan, M. (2016). The effects of a one-to-one iPad initiative: A case study (Doctoral dissertation, The University of Wisconsin-Milwaukee).

[15]. Rafiki, M. (2015). Pedagogical integration of the iPad to enhance teaching and learning of grade 10 life sciences (Doctoral dissertation, University of the Witwatersrand, Faculty of Humanities, School of Education).

[16]. Pegrum, M., Howitt, C., \& Striepe, M. (2013). Learning to take the tablet: How pre-service teachers use iPads to facilitate their learning. Australasian Journal of Educational Technology, 29(4), 464-479.

[17]. Poore, D. M. (2015). Professional Development for the Use of iPads in Instruction. Walden University.
[18]. Hargis, J., Cavanaugh, C., Kamali, T., \& Soto, M. (2014). A federal higher education iPad mobile learning initiative: Triangulation of data to determine early effectiveness. Innovative Higher Education, 39(1), 45-57. doi: 10.1007/s10755-0139259-y.

[19]. Shen, Y. W. (2016). An evaluation of the impact of using ipads in teacher education. The Online Journal of New Horizons in Education-October, 6(4).

[20]. Dogan, B., \& Almus, K. (2014). School administrators' use of iPads: Impact of training and attitudes toward school use. Computers in the Schools, 31(3), 233-250.

[21]. Rossing, J. P., Miller, W. M., Cecil, A. K., \& Stamper, S. E. (2012). iLearning: The Future of Higher Education? Student Perceptions on Learning with Mobile Tablets. Journal of Scholarship of Teaching and Learning, 12(2), 1-26.

[22]. Diemer, T. T., Fernandez, E., \& Streepey, J. W. (2012). Student perceptions of classroom engagement and learning using iPads. Journal of Teaching and Learning with Technology, 13-25.

[23]. Lindsey, J. (2011). Leading change:"going green" with iPads. Academic Leadership: The Online Journal, 9(3), 12.

[24]. Gong, Z., \& Wallace, J. D. (2012). A comparative analysis of iPad and other M-learning technologies: exploring students' view of adoption, potentials, and challenges. Journal of Literacy and Technology, 13(1), 2-29.

[25]. Mang, C. F., \& Wardley, L. J. (2012). Effective adoption of tablets in post-secondary education: Recommendations based on a trial of iPads in university classes. Journal of Information Technology Education, 11(1), 301-317.

[26]. Hill, J., Nuss, M., Middendorf, B., Cervero, R., \& Gaines, J. (2012, October). Using iPads to enhance teaching and learning in third-year medical clerkships. In E-Learn: World Conference on E-Learning in Corporate, Government, Healthcare, and Higher Education (pp. 1482-1488). Association for the Advancement of Computing in Education (AACE).

[27]. Chou, C. C., Block, L., \& Jesness, R. (2014). Strategies and Challenges in Ipad Initiative. International Association for the Development of the Information Society. 